Podplukovník Ing. Radek Dubec, Ph.D., Ing. Ján Spišák, Ph.D. Východiska tvorby modulárních struktur

\title{
Basic Elements of Modular Force Structures
}

\section{Abstrakt:}

Článek je shrnutím výsledků řešení projektu obranného výzkumu STRUKTURA: Tvorba modulárních struktur úkolových uskupení pro celé spektrum operací a jejich ověrování s využitím tvorby koncepcí a experimentování-CD\&E. Je zaměřen na objasnění problematiky definování modulủ jako základního prvku modularity a možné prístupy $k$ výběru hodnocení a formování modulárních úkolových uskupení. Cílem článku je pojednat o možnostech tvorby úkolových uskupení a generování sil v podmínkách definovaných a popsaných scénář̀u. Hlavní části článku vymezuji determinanty organizace modulárních struktur a jejich popis.

\section{Abstract:}

The article is a summary of the results of the defence research project STRUCTURE: Development of the Modular Task Force Structure for the whole spectrum of operations and their verification using $C D \& E$. The article is aimed at addressing the definition of modules as a basic element of modularity and possible approaches to the evaluation and selection of forming of modular task forces. The main parts of the article define the determinants of the organization of modular structures and their description.

\section{Klíčová slova:}

Modulární síly, modulární struktury, proces plánování, scénár̆, bezpečnostní hrozby, charakteristiky modulárních sil.

\section{Key words:}

Modular forces, modular structures, planning process, scenario, security threats, characteristics of modular forces.

\section{Úvod}

Modularita a teorie modularity jako manažerský přístup v posledním období prošla a stále prochází značným rozvojem spojeným se stále se rozšiřujícím zájmem o její zavedení ve všech možných oblastech lidské činnosti. V aplikaci teorie obecných systémů na poli matematiky, psychologie, biologie a dalších oblastí vědy je naprosto běžným a zažitým termínem modularita nebo koncept modularity. Značně frekventovaný začíná být tento pojem v oblasti rozvoje, tvorby či modelování organizačních uspořádání. 
V poslední době se pojem modularita objevuje i v oblasti vojenství jako např. modulární uspořádání jednotek, modulární organizační schéma, modulární design.

I když je modularita stále více uplatňována především v produkci zboží a strukturování produktů ve výrobě, stále zůstává velké množství neobjasněných oblastí modularity směrem $\mathrm{k}$ lepšímu pochopení některých principů modulárních organizačních struktur. Měnící se bezpečnostní prostř̌edí s novými hrozbami přineslo nové požadavky na ozbrojené síly a jejich operační použití. V rámci Aliance se jedním z často používaných nástrojů vojenské spolupráce stává vytváření mnohonárodních úkolových uskupení, která vyžadují určitou formu modularity národních př́spěvků do těchto společných vojenských jednotek.

V současné době vlivem ekonomické krize a snížením zdrojového rámce nebude pravděpodobně možné kalkulovat s využitím dostatečného množství sil a prostředků, které by zabezpečilo splnění operačních úkolů v takovém rozsahu, jako u operací již ukončených. Orgány odpovědné za plánování operací se na základě tohoto stavu dostávají do složité situace, kdy ke splnění požadovaných schopností budou muset využít nižší množství sil a prostředků.

V procesu politicko-vojenského plánování se vytvářejí úkolová uskupení, která vyžadují modulární strukturu příspěvků od jednotlivých národů (spojenců) na základě požadavku. NATO a EU nedisponují vlastními stálými vojenskými silami (jednotkami). Proto v rámci plánování operací je vždy nutné přistoupit k procesu operačního plánování a tvorby sil, tedy vytvoření takové struktury sil, která bude disponovat potřebnými schopnostmi a kapacitami pro dosažení požadovaných cílů operace.

\section{Východiska tvorby organizačních struktur úkolových uskupení}

Měnící se bezpečnostní prostředí s novými hrozbami determinuje nové požadavky na ozbrojené síly a jejich operační použití. $\mathrm{V}$ rámci aliance je jedním z používaných nástrojů vojenské spolupráce vytváření mnohonárodních úkolových uskupení na principu modularity.

Celý proces vytváření organizačních struktur úkolových uskupení do operací pod vedením NATO (EU, OSN) nebo ad hoc vytvořených koalic je ovlivněn řadou faktorů, které mají na národní úrovni podstatný vliv na obsahový a časový průběh samotného procesu tvorby úkolových uskupení.

Primárním krokem pro tvorbu a zavedení modulárních organizačních struktur je definovat moduly a popsat třídění modularity, metody a související metriky, jako základ pro zavedení a využívání modulárního přístupů k tvorbě organizačních struktur a vytváření úkolových uskupení na základě modularity. [1]

Základní filozofií možného použití Armády České republiky ve vojenských operacích je možnost působení v různých druzích operací, jejichž rozsah, obsah i naléhavost, jsou a budou velmi rozdílné. Tomuto širokému spektru použití je přizpůsobována organizační struktura nasazovaných jednotek AČR, počty osob, vybavení zbraňovými systémy technikou a materiálem. Pro plnění úkolů budou vytvářená úkolová uskupení složena z modulů, které budou mít stanovené schopnosti. Moduly a jejich schopnosti jsou tedy základem pro tvorbu organizačních struktur vyčleňovaných úkolových uskupení. 
Z hlediska modularity je důležité, že schopnosti AČR představují to, co jednotlivé složky, jednotky a armáda jako celek mají umět, znát a být schopny realizovat v přípravě k nasazení a v rámci uskutečňované operace. Jednotlivé schopnosti se navzájem doplňují, jsou propojeny a jsou na sobě závislé. [2]

Schopností se rozumí „soubor nezbytných vlastnostíjednotlivce, organizačního celku rezortu Ministerstva obrany nebo charakteristik systému (např. zbraňového) $\boldsymbol{k}$ vytvoření požadovaného efektu (napr. splnění bojového úkolu, dosažení cíle) “. [3, s. 3]

Základním nositelem schopností v rezortu Ministerstva obrany je organizační celek, jehož schopnosti vycházejí z tabulek počtů a jsou definovány úrovní jeho připravenosti k činnosti podle jeho poslání a schopnostmi interoperability s ozbrojenými silami členských států Organizace Severoatlantické smlouvy (NATO) a Evropské unie (EU).

Schopnost je ,způsobilost ozbrojených sil efektivně působit v krizových situacích a válečných konfliktech. Je podmíněna dostatkem připraveného personálu, odpovídající organizační strukturou, kvalitou výzbroje a techniky, adekvátními zásobami, úrovní výcviku a všestranného zabezpečení. Nositelem schopností je organizační prvek (vojenský útvar/zařizení), jejich skupina nebo jen část organizačního prvku (jednotka). “ $[4$, s. 168]

\section{Modularita}

V souladu s Doktrínou AČR z roku 2010 je modularita „...základem struktury armády. Z organizačně vytvořených modulárních taktických prvků se tvoři společná národní a mnohonárodní úkolová uskupení. Jejich kvalitativní i kvantitativní parametry musí odpovídat charakteru plněných úkolů. Jednotky všech druhů vojsk a služeb různého stupně velení jsou vyčleňovány pro potřeby vytváření společných mnohonárodních úkolových uskupení. Schopnosti budou přizpiosobovány konkrétním potrebám operace. Základním modulárním prvkem je stupeň družstvo/osádka/obsluha. “ [4, s. 108]

Princip modularity a naplnění požadovaných schopností je uplatňován také při vyčleňování jednotek pro potřebu výstavby společných aliančních sil rychlé reakce. Modulární jednotky jsou založeny na rotačním principu. Přispívají k udržení operačních schopností mnohonárodních bojových uskupení. Modulární jednotky musí mít na jedné straně schopnost opakovaného operačního nasazení, na straně druhé musí být v organizační struktuře AČR vytvářeny moduly pro zajištění rotace se stejnými operačními schopnostmi. S modularitou bojových útvarů je spojena potřeba modularity jednotek bojové podpory a logistiky. Vzájemná sladěnost a koordinovanost zavádění modularity u jednotek a útvarů zvyšuje účinnost a efektivitu celkových operačních schopností AČR.

Modulární systém je systém sestavený z jednotlivých modulů. Je tvořen postupným začleňováním modulů do funkčního systému podle konkrétních požadavků. Pro funkčnost systému je počet modulů variabilní. Stejně tak jako termín modul je termín modulární systém používán velmi univerzálně a prakticky ve všech odvětvích.

Pro účely operační praxe jsou vydefinovány základní moduly, které jsou skládány do množin s cílem vytvořit modulární systém určený ke splnění konkrétních úkolů dané operace. 
„Modul je základní stavební prvek (entita, organizační struktura), ze kterého je tvořna struktura společného národního nebo mnohonárodního úkolového uskupení v podmínkách konkrétní operace. Je určený ke splnění odborného úkolu (úkoli̊) nebo k naplnění požadované schopnosti (schopností) samostatně nebo ve vzájemné vazbě s dalšími moduly. " [1, s. 9]

Cílem tvorby úkolových uskupení je vytvořit organizační struktury jednotek, složených z jednotlivých modulů schopných naplnit operační požadavky na schopnosti, které bude možné kombinovat. AČR poskytuje síly s požadovanými schopnostmi, velikostí, odbornou strukturou a personálním obsazením. Konkrétní požadavky na schopnosti při konkrétní operaci determinují velikost, strukturu a složení sil, které se budou u každé operace lišit. Tvorba úkolového uskupení je kombinování modulů v závislosti na požadovaných schopnostech, cílech operace, úkolech operace, geografickém prostoru, časovém hledisku atd. (obr. 1). Tvorba úkolového uskupení je předmětem operačního plánování.

Struktura úkolového uskupení složeného z jednotlivých modulů musí vytvořit předpoklady pro naplnění cílů, úkolů a požadovaných schopností konkrétní operace. [2]

Kombinace modulů (jednotek) a vytvoření vhodné struktury úkolového uskupení pro operaci musí vytvořit velitelům úkolových uskupení prostor pro efektivní využití sil a prostředků úkolového uskupení. Promyšlená součinnost a kombinace jednotlivých modulů úkolového uskupení vytváří předpoklady účelně a efektivně reagovat na situace, které v rámci plnění cílů operace vznikají. Velitelé úkolového uskupení jsou schopni variabilně $\mathrm{v}$ případě potřeby měnit bojovou sestavu jednotky, reagovat na nové úkoly a požadavky podle podmínek a vývoje operace. Modulární struktura umožňuje velitelům úkolových uskupení způsobilost mimořádné agility a schopnosti reakce na vzniklé situace. [2]

\section{Faktory ovlivňující tvorbu modulárních uskupení}

Samotná tvorba modulárních uskupení je ovlivněna řadou aspektů. K základním patří bezpečnostní hrozby, scénář, charakter operace - zpravidla odpovídající danému scénáři, úkol (úkoly) v operaci, jenž vyplyne z charakteru (typu) operace samotné, základní a specifické schopnosti, jež budou požadovány po příslušnících ozbrojených sil, plnících dané úkoly. Těmto aspektům bude odpovídat struktura úkolového uskupení tvořená z modulů působících samostatně nebo v součinnosti s dalšími moduly.

\section{Bezpečnostní hrozby}

Prostředí, které ovlivňuje bezpečnost České republiky, neustále prochází dynamickými změnami a jeho předvídatelnost se vzhledem k rostoucí provázanosti bezpečnostních trendů a faktorů snižuje. Bezpečnostní hrozby, jejich zdroje a nositelé, mají jak státní, tak stále více i nestátní a nadnárodní charakter. Vnitřní a vnější hrozby se prolínají a rozdíly mezi nimi se stírají. Tyto aspekty mají zásadní dopad na přístup k zajištění obrany a bezpečnosti. Roste význam mezinárodního komplexního přístupu, který kombinuje použití vojenských a civilních nástrojů, včetně diplomatických a ekonomických prostředků k předcházení hrozeb a zmírnění jejich negativních vlivů. 


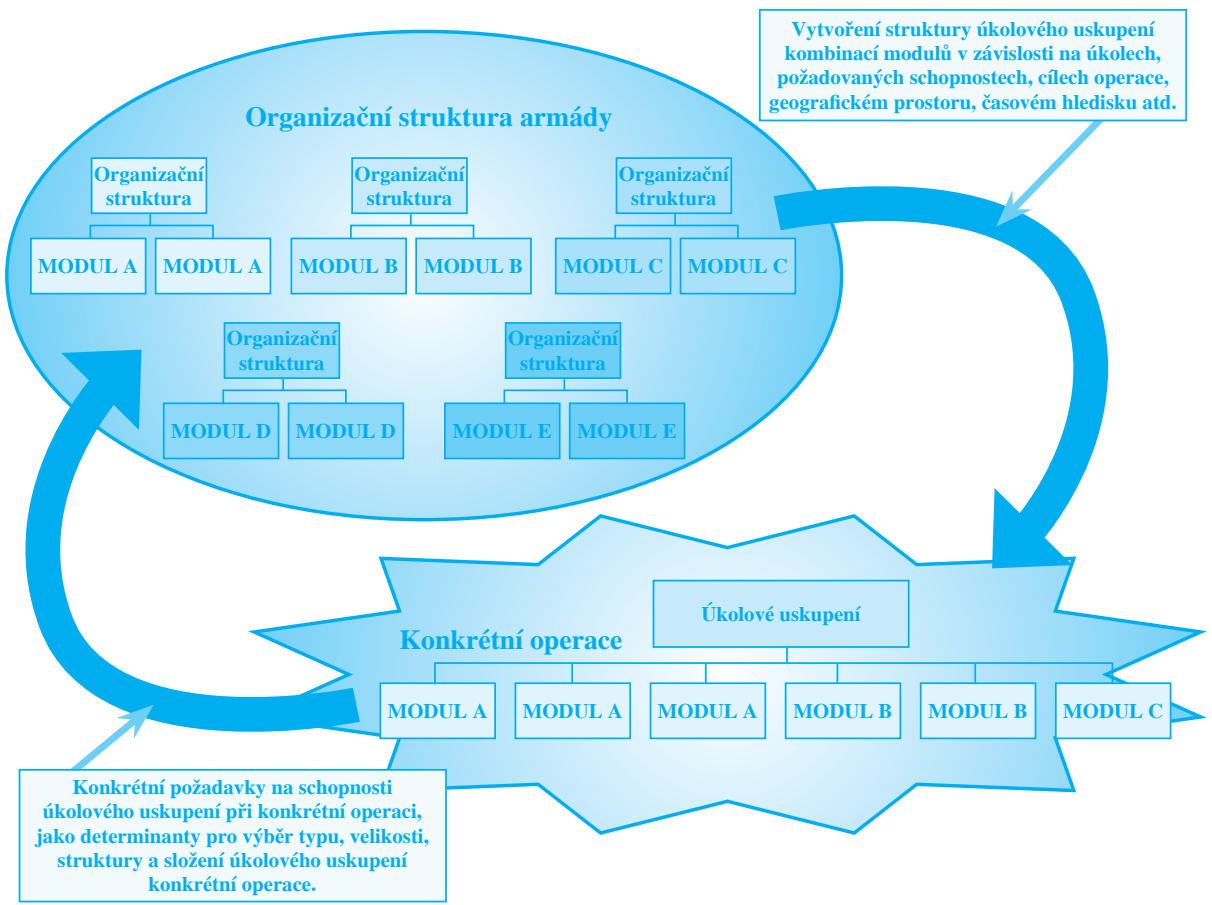

Obr. 1: Tvorba úkolových uskupení pomocí modulárního přistupu vzhledem k požadovaným schopnostem konkrétní operace [1, s. 10]

Podle původu či původce lze všechny hrozby dělit na tř̌i základní typy [5]:

• úmyslně způsobené člověkem (válečná agrese, trestná činnost, politické násilí, sabotáže atd.),

- neúmyslně způsobené člověkem (technologické a průmyslové havárie, selhání systémů či prvků kritické infrastruktury),

- způsobené prírodou (živelní pohromy, prrírodní katastrofy).

Bezpečností strategie ČR identifikuje řadu bezpečnostních hrozeb a výzev, jež mohou mít přímý dopad na bezpečnost našeho státu, a tak nepř́iznivě ovlivňovat naše životní, strategické a další významné zájmy. K takovým patří např̀. zajištění svrchované existence, územní celistvosti a politické nezávislosti ČR, zachování všech náležitostí demokratického právního státu včetně záruky a ochrany základních lidských práv a svobod obyvatel, bezpečnost a stabilita, především v euroatlantickém prostoru, prevence a zvládání místních a regionálních konfliktů a zmírňování jejich následků, zachování globální stabilizační role a zvýšení efektivnosti OSN, posilování soudržnosti a efektivnosti NATO a EU a zachování funkční a věrohodné transatlantické vazby, naplňování strategického partnerství mezi NATO a EU, včetně posilování jejich spolupráce při komplementárním rozvíjení obranných a bezpečnostních schopností a další.

Pravděpodobnost přímého ohrožení území ČR masivním vojenským útokem je nízká. Základní garancí tohoto př́íznivého stavu je členství ČR v NATO a EU a dobré vztahy se sousedními zeměmi. S tímto stavem však kontrastuje nárůst asymetrických 
bezpečnostních hrozeb. Ty jsou spojeny s trendy v globálním prostředí, které posilují jejich potenciál a zvyšují možnost šiřrení hrozeb z relativně vzdálených oblastí místních či regionálních konfliktů a napětí. Charakteristickým rysem současného prostředí je skutečnost, že i nestabilita a konflikty za hranicemi Evropy mohou mít přímý dopad na naši bezpečnost.

V bezpečnostním prostř̌edí, kde se ČR nachází, lze identifikovat další specifické hrozby pro její bezpečnost. Tyto nejsou čistě vojenského charakteru, nemají přímý dopad na její bezpečnost, ale ohrožují její spojence. K takovým patří např. politický extremismus a jeho projevy (především terorismus), šiřené zbraní hromadného ničení a jejich nosičů a jejich možné použití, kybernetické útoky, nestabilita a regionální konflikty v euroatlantickém prostoru a jeho okolí, rozpad státní autority v konfliktem zasažených oblastech a vznik zhroucených států, masové nepokoje a sabotáže, negativní aspekty mezinárodní migrace, organizovaný zločin a korupce, ohrožení funkčnosti kritické infrastruktury (komunikační, dopravní a energetické), přerušení dodávek strategických surovin nebo energie, oslabení mezinárodních organizací a institucí klíčových pro bezpečnost ČR, především Severoatlantické aliance a Evropské unie, vytváření sfér vlivu prostřednictvím politického, ekonomického či vojenského nátlaku; regionální a místní konflikty v rámci euroatlantického prostoru i v jeho širším sousedství, včetně dlouhodobě nevyřešených konfliktů, humanitární katastrofy bez ohledu na jejich prř́činy, pohromy př́rodního a antropogenního původu a jiné mimořádné události. [6]

\section{Scénáře použití ozbrojených sill}

Scénáře použití ozbrojených sil představují podrobný popis podmínek budoucí operační situace, ve které budou ozbrojené síly plnit stanovené úkoly. Scénáře jsou klíčovým prvkem pro plánování na základě schopností (CBP - Capability Based Planning), zahájení procesů pro tvorbu sil, zpracování seznamu úkolů a cílů schopností, následnou tvorbu schopností a tvorbu investičních plánů. Scénáře poskytují příležitost pro lepší rozhodování vzhledem k tomu, jaké schopnosti budou v operacích požadovány. Účelem scénářů je rovněž usnadnit analýzu, jak co nejlépe splnit úkoly mise (operace), naplnit stanovené cíle a přispět k dosažení požadovaného konečného stavu.

Plánovací scénáře jsou prostředkem konkretizace priorit. Jde o predikované plánované situace, které budou vyžadovat použití ozbrojených sil (použití síly). Scénáře nejsou predikcí budoucnosti, ale metodou minimalizace hrozeb tím, že jsou k těmto scénářủm hledány varianty řešení, jak těmto hrozbám předejít, jak je eliminovat, nebo jak omezit jejich důsledky. [7] Scénáře jsou odvíjeny od popisu bezpečnostního a operačního prostředí definovaného ve strategických dokumentech nebo prognostických studiích. Nevýhodou je, že v těchto dokumentech je abstrahována všeobecná podstata hrozeb a není tedy možné na základě této abstrakce přesně definovat potřebné budoucí schopnosti ozbrojených sil. Strategické dokumenty neobsahují informace týkající se konkrétního vojenského úkolu, protivníka a dalších aktérů přítomných v daném operačním prostředí a jeho doménách. Tyto plánovací předpoklady lze vyjádřit formou scénáře nebo scénářu. [8]

Samotné scénáře umožňují hodnotit jaké nejpravděpodobnější základní (klíčové) schopnosti bude nutno vyžadovat, analyzovat jejich dopad a význam v dlouhodobém a střednědobém horizontu a předvídat jaké technologie bude nutno propojit (přidružit) s požadavky souvisejícími s těmito klíčovými i dalšími schopnostmi. 
Použití ozbrojených sil ČR předpokládá, že tyto budou schopny se angažovat v operacích co do povahy a intenzity velmi rozdílných, kdy požadované cíle se mohou podstatně měnit od operace k operaci v závislosti na politickém a obzvláště vojenském kontextu zapojení. Lze říci, že bezpečnostní hrozby ovlivňující zájmy ČR př́imo souvisí s použitím ozbrojených sil podle předem uvažovaných (vytvořených) scénářů. Základní přehled scénář̌̀ [9] použití ozbrojených sil ČR zahrnuje čtyři scénáře, z toho tři scénáře reagující na ohrožení vojenské povahy a jeden scénář pro podporu řešení krizí nevojenského charakteru.

Scénář 1 počítá s účasti ozbrojených sil ČR k řešení významné hrozby, při které bude nutná kolektivní obrana teritoria NATO (EU). [10] V těchto podmínkách se předpokládá dostatečně dlouhá varovná doba (několika let), během které bude nutno přistoupit k progresivní adaptaci, změně velikosti a způsobu použití nástrojů obrany oproti těm, kterými ČR disponuje v době míru.

Scénáře 2 a 3 [11] charakterizují zapojení ČR do stabilizační, resp. mírové operace jednotkami, které jsou vytvořeny ze systemizovaných míst ozbrojených sil ČR. Zapojení do těchto operací nevyžaduje vyhlášení stavu ohrožení státu ani válečného stavu na území ČR. Tyto scénáře slouží pro zapojení ozbrojených sil ČR do řešení situací, které nejsou spojeny se zajišt’ováním obrany ČR před vnějším napadením.

Scénář 4 představuje situaci, ve které ozbrojené síly ČR vedou operaci v krizových situacích nevojenského charakteru, a to rovněž silami a prostředky, které má AČR $\mathrm{k}$ dispozici v době míru. [12]

\section{Celkový přehled scénářů (S1-S4) je následující:}

S1: Vedení bojových operací v rámci kolektivní obrany teritoria NATO a EU včetně vedení vojenské činnosti na území ČR.

S2: Vedení stabilizační operace (operace k umožnění stabilizace, tzv. security operations), kam patří zejména protipovstalecké operace (COIN - Counterinsurgency), vedené mimo teritorium NATO a EU.

S3: Vedení mírové operace (operace na podporu míru) vedené mimo teritorium NATO a EU.

S4: Vedení operace na podporu civilních orgánů (humanitární operace) v krizových situacích nevojenského charakteru vedené na území státu i mimo teritorium NATO a EU.

Uvedené scénáře jsou základním rámcem všeobecného použití ozbrojených sil nejen ČR, ale i ostatních členských států NATO (EU).

\section{S1 - Kolektivní obrana teritoria NATO a EU včetně vedení vojenské činnosti na území ČR}

Scénář předpokládá vznik mezinárodní krizové situace s možnou vojenskou hrozbou proti ČR (NATO, EU). Vojenské ohrožení bude indikováno s dostatečným časovým předstihem s varovací dobou minimálně tř́i až pět let.

Bude se jednat se o rozsáhlý konflikt vysoké intenzity, u něhož hrozí přeměna v konflikt globální. Střet bude veden zbraněmi na vysoké technologické úrovni a nelze vyloučit omezené použití jaderných zbraní vzhledem k prrítomnosti jaderných velmocí v regionu, existenci jaderných arzenálů a jaderných zařízení. Nelze vyloučit výrazné účinky zbraní 
hromadného ničení na území státu a je nutné počítat s následky zničení nebo poškození důležitých a ekologicky nebezpečných energetických a průmyslových komplexů.

Operace podle tohoto scénáře budou zpravidla komplexní a vyžadují politická, civilní a vojenská opatření a nástroje. V rámci jedné operace nelze vyloučit střídání či prolínání charakteru plněných úkolů a proměnlivou intenzitu jejích jednotlivých fází. Protivník používá symetrické i asymetrické způsoby (metody) boje, mnohdy mizí hranice mezi bojovou zónou a civilním zázemím.

Podle tohoto scénáře bude organizována maximálně efektivní obrana území a obyvatelstva NATO nebo EU před přímým útokem konvenčních i jaderných, biologických a chemických zbraní nepř́tele, která bude zajištěna domácími i spojeneckými silami, a dále posílení a podpora spojeneckých sil v operacích realizovaných mimo hranice našeho státu, vedených v souladu s politikou OSN, OBSE a EU. Konflikt bude probíhat v různorodém a složitém operačním prostředí, ve kterém budou působit vládní a nevládní organizace, mohou se zapojit i nečlenské země NATO a množství dalších účastníků (kombatantů i nekombatantů), pozorovatelů (médií) a jiných zainteresovaných stran, frakcí a organizací. [5]

Během probíhajícího konfliktu i bezprostředně po jeho skončení bude také nutná účast části ozbrojených sil ČR na zachovávání veřejného pořádku, zajištění základních funkcí státní správy, spoluúčast na ochraně zdrojů a distribuci základních surovin, ochrana důležitých objektů pro obranu státu, včetně mimořádných hodnot a likvidace rozsáhlých ekologických následků válečných operací.

Politické cíle - konečný stav:

a) zajistit bezpečnost, stabilitu a pořádek na území ČR (teritoriu NATO, resp. EU) ve smyslu naplnění spojeneckých smluv a zásad mezinárodního práva,

b) obnovit státní suverenitu a svrchovanost na území ČR (zemi NATO, resp. EU).

Vojenské cíle - konečný stav:

a) zajistit obranu C̆R v souladu s národními bezpečnostními zájmy a závazky, zabezpečit kolektivní obranu teritoria NATO a EU,

b) v součinnosti s mnohonárodními silami odrazit a eliminovat účinky útoku,

c) bránit obyvatelstvo, majetek, infrastrukturu a zdroje,

d) po odražení útoků se podílet na zachovávání veřejného pořádku, zajištění a obnovení základních funkcí státní správy.

\section{S2 - Stabilizační operace vedené mimo teritorium NATO a EU}

Stabilizační operace bude vedena zpravidla pod řízením NATO nebo EU, na základě rozhodnutí OSN. Tyto operace mohou být často uskutečňovány i bez souhlasu bojujících stran. Bude vedena formou koaliční nátlakové operace s cílem přimět účastníky konfliktu k ukončení bojových aktivit, oddělení znepřátelených stran pomocí ozbrojených sil, ukončení násilí vůči civilnímu obyvatelstvu a k neutralizaci jejich ozbrojených sil. Ozbrojené síly ČR musí mít schopnosti adekvátní charakteru, prostředí a intenzitě konfliktu.

Politické cúle - konečný stav:

a) přítomností ozbrojených sil se podílet na vybudování bezpečnosti a stability v regionu, 
b) prokázat vůli a schopnost zajistit rezoluci OSN,

c) obnovit demokratický výkon vládní moci,

d) zajistit mezinárodní právo a pořádek.

Vojenské cíle - konečný stav:

a) oddělit válčící strany a zastavit neprrátelské akce,

b) nasazením vojenských sil spolu s ostatními nástroji (politickými, občanskými, ekonomickými) a vládními i nevládními organizacemi vytvořit podmínky pro prechod ke stabilizační operaci.

\section{S3 - Operace na podporu a udržení míru vedené mimo teritorium NATO a EU}

Operace na podporu nebo udržení míru jsou uskutečňovány zpravidla se souhlasem znepřátelených stran pod patronátem NATO nebo EU, kdy na základě rozhodnutí Rady bezpečnosti OSN bude vyslán do prostoru potřebný kontingent sil. Vyslání příspěvku ozbrojených sil ČR do krizové oblasti podléhá schválení Parlamentu ČR. [6]

Smyslem takovéto operace bude zajištění stabilizace, rekonstrukce a vojenská pomoc. Cílem bude předejít vzniku či eskalaci konfliktu, dohlížet na aktivity ozbrojených sil obou stran, zabránit jim v zahájení či obnovení bojových akcí a páchání násilí na civilním obyvatelstvu, a zajistit tak postupnou stabilizaci a obnovu mírového života. Půjde zpravidla o vedení koaliční operace s nižší úrovní intenzity.

Politické cúle - konečný stav:

a) obnovit bezpečnost a stabilitu země a pomoci př́i opětovném vybudování přiměřené úrovně státní struktury,

b) prosadit dodržování smluv k uzavření příměří,

c) vyšetřovat válečné zločiny, pátrat po ilegálních ozbrojených skupinách,

d) naplnit vůli a rozhodnutí stanovená rezolucemi OSN,

e) zajistit mezinárodní právo a pořádek, zajistit přechod k fungování demokratické společnosti.

Vojenské cíle - konečný stav:

vytvořit stabilní bezpečnostní prostředí a nedovolit agresivní projevy nepřátelství.

a) prosadit plnění rezoluce OSN a předat odpovědnost za garanci bezpečnosti místním orgánům,

b) další vojenská prrítomnost není nadále potřebná.

\section{S4 - Operace na podporu civilních orgánů v krizových situacích nevojenského charakteru vedené na území státu nebo i mimo teritorium NATO a EU}

Na území ČR budou i nadále ozbrojené síly připraveny poskytnout v nezbytném rozsahu a podle dostupnosti na podporu integrovaného záchranného systému (IZS) nebo Policie ČR, síly a prostředky, které mohou být dále posíleny jednotkami aktivních 
záloh. V principu jsou ve prospěch integrovaného záchranného systému nebo Policie ČR využitelné všechny síly a prostředky ozbrojených sil v souladu s př́íslušnými nařízeními, směrnicemi a rámcovými dohodami.

Mimo území ČR jsou ozbrojené síly schopny působit na podporu civilních orgánů a organizací, a to zejména v př́ípadě poskytnutí humanitární pomoci. Poskytnutí sil a prostředkủ bude podle okamžitých možností.

\section{Řešení nevojenských krizových situací na území ČR}

Možnosti použití ozbrojených sil ČR k řešení nevojenských krizových situací na i mimo území ČR vychází z následujících dílčích scénářu ohrožení:

(S4.1) Vznik živelních pohrom vlivem př́rodních jevů velkého rozsahu na území ČR (požáry, povodně), průmyslové havárie velkého rozsahu a rozsáhlé chemické, biologické nebo radiační ohrožení, narušení produktovodů a energovodů a vznik epidemií velkého rozsahu a nákaz zvěre, které nelze zvládnout silami a prostředky IZS. $V$ rámci tohoto dílčího scénáře lze působit i mimo území ČR.

Použití ozbrojených sil: Nasazení dalších sil a prostředků k posílení integrovaného záchranného systému ČR.

(S4.2) Narušení zákonnosti (terorismus, velká kriminalita, ohrožení demokratických základů státu) a migrační vlny velkého rozsahu, které nelze zvládnout silami a prostředky Policie ČR při zajišstování vnitřní bezpečnosti a veřejného pořádku.

Použití ozbrojených sil: Posílení a plnění úkolů Policie ČR silami a prostředky ozbrojených sil.

(S4.3) Vzhledem k angažovanosti ČR v rámci operací NATO, EU a OSN je možno predikovat zvýšenou aktivitu teroristických skupin na území ČR a s tím související možnosti provedení teroristického útoku vedeného ze vzduchu na cíle v ČR. Předem není možné přesně určit cíle a druh použitého prostředku napadení $\mathrm{v}$ př́padě pokusu o teroristický útok. Ohroženy budou s největší pravděpodobností zařízení, jejichž poškozením mohou být způsobeny škody s masovým účinkem na místa s vysokou koncentrací obyvatelstva.

Použití ozbrojených sil: Připravené síly a prostředky k zamezení provedení teroristického útoku vedeného ze vzduchu ve vzdušném prostoru ČR.

(S4.4) Hrozba pravděpodobného napadení chráněných objektů důležitých pro obranu státu, která vychází ze současné bezpečnostní situace v ČR hodnocené v mezinárodním kontextu.

Použití ozbrojených sil: Vyčleněnými silami a prostředky podle plánu.

Hlavní scénáře je možné dále členit na určité sub-scénáře, které mohou představovat dílčí rámec působení ozbrojených sil ve stabilizačních operacích a operacích na podporu míru. Zkušenosti z působení NATO ve vojenských operacích vedených v posledních letech naznačují, že k takovým sub-scénářủm by mohly patřit např.:

口 Sub-scénáŕ 1: Záchrana zajatců v zastavěném prostoru $v$ oblasti s kritickou infrastrukturou. 


\section{Sub-scénář 2: Hrozba použití zbraně hromadného ničeni v zastavěném prostoru.}

- Sub-scénáŕ 3: Ochrana klíčových zařizení a infrastruktury.

Sub-scénář 4: Zajištění distribuce humanitární pomoci v krizové oblasti.

$\square$ Sub-scénář 5: Ochrana a evakuace menšinové populace.

$\square$ Sub-scénář 6: Eliminace asymetrické hrozby.

$\square$ Sub-scénář 7 - N: Ostatní, v této metodice dále neidentifikované.

Každý z těchto sub-scénářu použití ozbrojených sil představuje popis charakteristických podmínek budoucí operační situace, ve které budou ozbrojené síly plnit stanovené úkoly. Přestože se může jevit, že jednotlivé sub-scénáře jsou svou povahou specifické a v některých případech i jedinečné, je zcela zřejmé, že charakter úkolů a činností, které přríslušníci ozbrojených sil budou muset v těchto sub-scénářích vykonávat, může být nebo bude společný a v mnoha případech se nebude zásadně odlišovat.

V závislosti na situaci a intenzitě činnosti protivníka nebo jiných aktérů, vyskytujících se v daném operačním prostoru, kteří se budou snažit zabránit plnění úkolů ozbrojených sil v rámci těchto sub-scénářů, náplní činnosti vlastních ozbrojených sil budou zejména základní stabilizační činnosti (bezpečnost a kontrola, podpora reformy bezpečnostního sektoru, budování schopností bezpečnostních sil hostitelského státu, počáteční obnova služeb a zařízení) a jejich doprovodní aktivity (např. hlídkování a prohledávání, pozorování/monitorování, eskortování, hlídání, poskytnutí humanitární pomoci nebo výcvik místních bezpečnostních sil).

Příslušníci ozbrojených sil budou rovněž plnit další specifické úkoly, vyplývající z povahy jednotlivých sub-scénářu. K takovým mohou patřit zabránění a blokování vstupu jednotlivých osob či skupin do prostoru nalodění, vylodění, výsadku, jejich zadržení a střežení, zabránění úniku toxických látek a jejich šíření, vyhledávání materiálu sloužícího k výrobě zbraní hromadného ničení nebo těchto zbraní samotných, identifikace, označení, stopování, zadržení a likvidace teroristů, zajištění bezpečnosti místního obyvatelstva zabráněním páchání násilí na něm, podpora boje proti terorismu zabráněním uskutečnění teroristických akci, zvládání davu, ochranu konvojů, zásob, zřízení a ochranu vstupních míst na základny (checkpoint), evakuaci jednotlivců a skupin pozemní, leteckou nebo námořní cestou a řadu jiných aktivit, vztažených $\mathrm{k}$ plnění úkolů v rámci základních scénářů nebo uvedených sub-scénářò.

Zkušenosti z historie ovšem naznačují, že v konfliktu rozdíl mezi válkou a mírem nelze vždy jednoznačně určit a oddělit. Ke změně situace a charakteru původního úkolu může dojít v průběhu krátké doby, kdy příslušníci ozbrojených sil budou vystavení nutnosti vedení nejen stabilizačních nebo mírových aktivit, ale rovněž aktivit útočných nebo obranných.

\section{Charakter operace}

Operační scénáře se stávají determinantem pro plánování a vedení vojenských operací v celém jejich spektru. Budoucí operace, na nichž se ozbrojené síly mohou podílet k eliminaci výše uvedených hrozeb, budou mnohem složitější než v minulosti. Základní terminologický slovník pojmů a definic NATO AAP-6, definuje operaci jako: 
„,Vojenskou činnost nebo provedení vojenského strategického, taktického, výcvikového, administrativního úkolu nebo poskytnutí pomoci, proces vedení boje, včetně přesunů, zásobování, útoku, obrany a manévru, které jsou nezbytné pro dosažení cílů jakékoli bitvy nebo kampaně (tažení). “ Komplexnější pojetí významu poskytuje doktrína Pozemní síly v operacích (2011), která ji definuje jako: „Souhrn souběžně probíhajicích základních činností (útočných, obranných, stabilizačních a jiných činností) v rámci hlavního zaměrení operace. " [14]

Vojenské operace probíhají v celém spektru konfliktu. Ovšem, žádný konflikt není obrazem pouze jednoho typu operace. V jakékoliv době může existovat prolínání různých situací, vyžadujících různý způsob přístupů k jejich řešení a různý způsob použití vojenské síly. Zatímco na jednom místě v rámci operačního prostoru může být poskytována humanitární pomoc, na dalším to může být intenzivní boj proti povstalcům, případně boj rovnocenných uskupení obrněných jednotek, opodál to může být boj v zastavěném prostoru. Další den může probíhat zajištování forenzních důkazů, obnovení dodávek elektrické energie, zajištění dodávky vody nebo jiných zásob pro civilní obyvatelstvo a znova návrat k bojové činnosti. Jednotlivé stavy míru, napětí a boje mohou být lokální nebo vše prostorové, rovněž jako jejich doba a intenzita. Každá krize může být komplexem různých bojových, protipovstaleckých, stabilizačních, mírových nebo podpůrných aktivit, jejichž hranice se často stírají a nejsou zcela zřejmé. Změny ve vývoji situace mohou nastat náhle a velmi rychle a mohou se dít se stoupající intenzitou a téměř nepřerušovaně.

Operace, jichž se budou příslušníci ozbrojených sil ČR zúčastňovat, mohou probíhat ve značné vzdálenosti od ČR, kdy účast těchto sil v principu není, vyjma arktických oblastí, geograficky omezena. Operace budou probíhat v různých operačních prostředích a ozbrojené síly se budou muset rychle přizpůsobovat proměnlivému vývoji operací, zahrnující operace vysoké intenzity, letální i neletální způsob vedení boje se širokou škálou různých stabilizačních, mírových, podpůrných nebo humanitárních aktivit, vyžadujících rozmanitý soubor schopností.

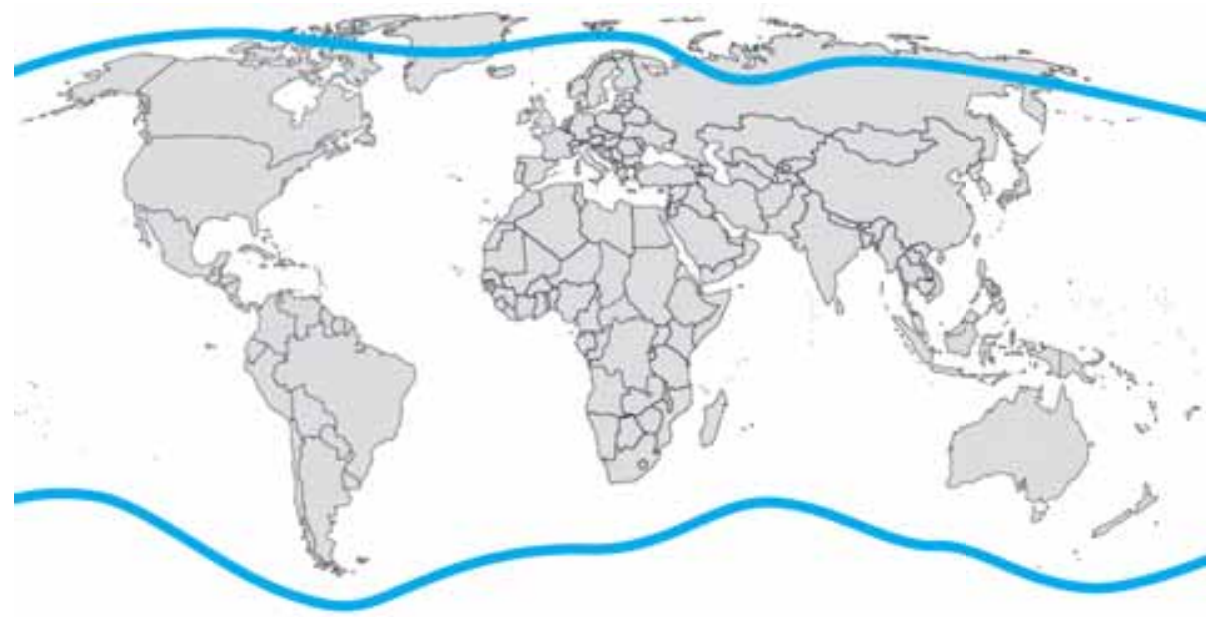

Obr. 2: Možný prostor nasazení př́slušníkủ OS ČR. Zdroj: BKO 2011 [13] 
Vojenské operace budou zpravidla probíhat současně na různých místech a proti různým aktérům. Nasazená úkolová uskupení budou zpravidla utvářena primárně na bázi organických jednotek, účelově doplněných specifickými moduly, především prvky bojové podpory a bojového zabezpečení. Rozsah nasazení profesionálních ozbrojených sil a jejích prostředků, včetně využití všeobecné branné povinnosti, bude záviset od velikosti, typu a rozsahu konfliktu, na kterém se bude ČR podílet.

Je nanejvýš pravděpodobné, že ozbrojené síly budou (zejména mimo území ČR) i nadále nasazovány v rámci širšího úsilí mezinárodního společenství, a to v souladu s principy Charty OSN v celém spektru operací vedených NATO, EU, OSN nebo ad hoc vytvářenými koalicemi. Predikce bezpečnostních hrozeb naznačuje, že možnost vzniku konfliktu, který by vyžadoval vedení kolektivní obrany, je v blízkém horizontu méně pravděpodobná. Naopak se předpokládá působení ozbrojených sil zejména za podmínek s charakteristickými znaky scénářù vedení stabilizačních operací a operací na podporu míru.

\section{Závěr}

Požadavek tvorby a nasazení modulárních struktur úkolových uskupení vychází z dlouhodobého procesu transformace ozbrojených sil za účelem optimalizace jejich organizačních struktur a efektivního využití jejich potenciálu při plnění úkolů ve vojenských operacích. [15]

V souladu s přijatými závazky o zajišt’ování kolektivní obrany se od národních ozbrojených sil očekává př́ispěvek v podobě modulárních jednotek, které budou spolu s jednotkami aliančních partnerů a dalších spojenců vytvářet mnohonárodní úkolová uskupení. Je předpoklad, že tento závazek bude v podmínkách ozbrojených sil realizovatelný všemi jejími součástmi.

Vytvořená úkolová uskupení budou složena z dílčích modulů se schopností samostatného nasazení a působení v rámci národních i mezinárodních společných operací. Variabilita sestavení těchto uskupení přináší možnosti efektivního využití dostupných zdrojů nejen lidských a finančních, ale i technických a materiálních.

Pro vytvoření podmínek pro zavedení modulární struktury je však nezbytné vytvoření teoretického základu a metodologického rámce využívání tohoto přístupu.

\section{Poznámky k textu a užitá literatura:}

[1] DUBEC, R. - HRŮZA, P. - SPIŠÁK, J. - ČERNÝ, J. Tvorba modulárních struktur úkolových uskupení. Praha: Powerprint s.r.o., Praha 6, 2012, 82 s. ISBN 978-80-87415-54-2.

[2] DUBEC, Radek. Analýza způsobů tvorby modulu a tvorby modulárních struktur úkolových uskupení. In Studie projektu obranného výzkumu STRUKTURA. Brno, 2011. 35 s. Ev.č. 81/9/27/2011-2994.

[3] Rozkaz Ministra obrany č. 66/2012. Plánování činnosti a rozvoje v rezortu Ministerstva obrany. Praha: Ministerstvo obrany České republiky, 2010. 11 s.

[4] Doktrína Armády České republiky. 2. vydání, Vyškov: Institut doktrín VeV-VA, 2010, str. 108.

[5] Comprehensive Operations Planning Directive. Allied Command Operations, Supreme Headquarters Allied Power Europe, Belgium, 2010, 407 s.

[6] SPIŠÁK, Ján. Procesy operačního plánování. In Studie projektu obranného výzkumu STRUKTURA. Brno, 2012, 49 s.

[7] PIKNER, I. - GALATÍK, V1. - SPIŠÁK, J. Zásady tvorby operačních koncepcí. Brno: Univerzita obrany, 2010, 73 s. ISBN 978-80-7231-755-4. 
[8] PIKNER, I. - GALATÍK, V1. - KRČMÁŘ, M. Nové přístupy k obrannému plánování v dlouhodobém horizontu: Scénáře a operační koncepce pro budoucí bezpečnostní prostředí. Vojenské rozhledy, 2011, roč. 20 (52), č. 3, s. 23-28, ISSN 2010-3292.

[9] Základní čtyři scénáře popisuje do určité míry Vojenská strategie ČR a další koncepční materiály, což je bráno do úvahy v plánu obrany ČR a s výhledem aplikováno v koncepci použití AČR. In Zpráva o zajištění obrany České republiky, dostupné na http://www.vlada.cz/assets/ppov/brs/dokumenty/Zpr_ va_o_zaji_t_n_obrany__esk__republiky.pdf.

[10] Aplikace čl. 5 WS (Washington Treaty). Plné znění zakládajícího dokumentu NATO na http://www. natoaktual.cz/na_zpravy.aspx?y=na_summit/washingtonskasmlouva.htm.

[11] NATO je charakterizuje jako NA5CRO (Non Article 5 Crisis Response Operations), tj. operace k řešení krizových situací mimo článek 5 WS.

[12] Použití ozbrojených sil v rámci mírového nasazení (PME - Peacetime Military Engagement) není v rámci těchto scénářů uvažováno jako samostatný scénár.

[13] Bílá kniha o obraně. Ministerstvo obrany České republiky, OKP-MO, 2011, 168 str. ISBN 978-807278-564-3 (české vydání). Dostupné na http://www.mocr.army.cz/informacni-servis/zpravodajstvi/ plne-zneni-bile-knihy-o-obrane-55515/.

[14] AAP-6, Slovník termínů a definic NATO (anglicky a francouzsky). Praha: Úřad pro obrannou standardizaci, katalogizaci a státní ověřování jakosti, Odbor obranné standardizace, 2010, 451 s. Tento slovník je k dispozici v elektronické formě na http://www.nato.int/docu/stanag/aap006/aap6.htm a intranetu (Minerva a Cronos); Pub-31-10-01, Pozemní síly v operacích. 1. vyd. Vyškov: Institut doktrín VeV-VA, 2011, $296 \mathrm{~s}$

[15] Dlouhodobá vize rezortu Ministerstva obrany. 1. vydání, Praha: MO ČR, 2008. 19 s. Dostupné na http://www.vlada.cz/assets/ppov/brs/dokumenty/dlouhodoba-vize-mo.pdf.

\section{Češi patří mezi nejlepší stratégy, tvrdí expertní studie v rámci EU}

Další skupiny zemí podle autorů se svými strategickými koncepcemi v celé řadě zaostávají. Třetí skupinu tvoří takzvaní „globalisté“. Sem patří Mad’arsko, Německo, Nizozemsko, Slovinsko a Španělsko. Tyto země podle srovnání většinou ,,jen popisují obecnou skutečnost tak, jak je“, aniž by stanovily své strategické cíle a změny, které pro jejich dosažení musí udělat.

\section{Flákači a zdrženliví}

Čtvrtou skupinou jsou „lokalisté“ - nejpočetnější skupina tvořená Bulharskem, Dánskem, Estonskem, Polskem, Rumunskem, Slovenskem, Litvou a Lotyšskem. Tyto země naopak prosazují operační úroveň za strategickou a zaměřují se na prostředky. Jejich hlavním cílem je zachování teritoriální celistvosti, a to i tváří tvář Rusku, které „alternativně považují za hrozbu i potencionálního partnera“. Pátou skupinu tvoří Irsko, Lucembursko, Malta a Rakousko a autoři je označují jako ,zdrženlivé“, protože se z různých důvodů nijak významně vytyčením strategických cílů nezabývají.

Poslední skupinou zemí, jejichž strategie jsou velmi zastaralé, a navíc nejeví př́lišný zájem je vzhledem k současnosti aktualizovat, jsou takzvaní „lenivci“. Sem experti zařadili Belgii, Itálii, Portugalsko a Řecko.

\section{natoaktual.cz, oficiální portál Informačního centra o NATO [21. června 2013] http://www.natoaktual.cz/cesi-mezi-nejlepsimi-strategy-dep /na_zpravy. aspx?c=A130624_170815_na_zpravy_m00.}

